\title{
Financial Ratio Analysis on Telecommunication Industry in Malaysia (Comparation between Maxis Berhad and Digi Berhad)
}

\author{
Yetti Tri Wulandari ${ }^{1}$ \\ ${ }^{1}$ University of Merdeka Malang, Jl. Terusan Raya Dieng 62-64, Malang, 65146, Indonesia
}

\begin{abstract}
This article analyzed financial ratio two leading telecommunication company in Malaysia Maxis Berhad and Digi Berhad. The analysis show Digi have better profitability ratios than Maxis Berhad. Efficiency ratio for both companies is almost the same performance. Digi have higher leverage ratio and higher liquidity ratio. Maxis have better market ratio.

Keywords: Financial Ratio Analysis; Telecommunication Companies of Malaysia
\end{abstract}

\section{INTRODUCTION}

The introduction of telephone of telephone services in Malaysia was started in the year 1981 in Kuala Lumpur, where the first telephone exchange installed. During that time, there were only 21 telephones in Kuala Lumpur, which can only be supported by 400 miles of telephones and telegraph lines during the initial development. In 1985, Telekom Malaysia had introduced mobile services in Malaysia, afterward the government had granted a number of licenses to private sector telecommunication operations in an effort to develop in the county's telecommunication industry and infrastructure. Afterwards, Malaysia Communication and Multimedia Commission (MCMC) was established as regulatory body.

In the past few years, the telecommunication industry in Malaysia has been led by the top 3 telecommunication company, Maxis Berhad, Digi Berhad and Celcom Axiata Berhad. The service that are being offered by the companies have significantly helped people to connect and communicate with others which makes their daily lives easier and convenient. The top 3 companies have been competing with each other to be the top in the industry. However, in the current and few years after, the number of telecommunication companies has rapidly increase for example, Umobile, Tunetalk and etc. These telecommunication market has been dominated by few major companies which actually is a threat to the existing and well established companies. The telecommunication market structure in Malaysia has become oligopoly due to the intense competition in the telecommunication market. In order to sustain and maintain their position and the top telecommunication companies, they would have considered the possible reactions rivals to its own pricing, output and advertising decision and strategies.

Maxis Berhad is a communication service company and provider in Malaysia that provides variety of mobile communication products and services. They offer mobile plans that consists of post-paid data plan, prepaid data plan, call plans, wireless broadband, WIFI - fibre internet, international roaming and residential fixed line services.

For business customers, Maxis offer cloud computing, data storage, machine-to-machine services, fixed high speeded internet, VSAT services (satellite based communications), call conferencing and variety of mobile plans. Maxis also provides online games and a music store for its customer to download multimedia content. Maxis most popular services is its prepaid brand, Hotlink, which currently serves over 9.5 million customers in Malaysia. Maxis have committed into a long-term investments into expanding their 4G LTE coverage so that all customers enjoy an uncompromised Internet experience and provide with their industry- leading Fibre and 5G-ready network, the widest and fastest in Malaysia

Digi is a mobile connectivity and internet services provider enabling 11.3 million Malaysians with advanced 4G+ network. They offer mobile voice, roaming and value-added services on both prepaid and contract bases. Also, the company also offer mobile connectivity, broadband, enhanced calling features, international roaming, wireless internet, and telephone services. Digi has desired to connect their customers to what matters most by providing relevant, personalized, and engaging digital products and services that will enhance their digital lifestyles. Listed on Bursa Malaysia, Digi is part of global telecommunications 
provider Telenor Group, and is a leader in driving progressive and responsible business practices.

\section{RESULTS AND DISCUSSIONS}

Financial Report for the Two Companies are:

Table 1. Maxis Berhad Group Statement Profit or Loss at year end 2018, 2017 \& 2016

\begin{tabular}{|l|c|l|l|}
\hline & $2018(\%)$ & $2017(\%)$ & $2016(\%)$ \\
\hline Revenue & 100.00 & 100.00 & 100.00 \\
\hline Traffic, commissions and other direct costs & -32.74 & -33.09 & -24.84 \\
\hline Spectrum licence fees & -2.67 & -2.10 & -1.71 \\
\hline Network costs & -9.62 & -8.35 & -9.20 \\
\hline Staff and resource costs & -6.59 & -6.12 & -6.11 \\
\hline Operation and maintenance costs & -5.11 & -3.63 & -3.70 \\
\hline Marketing costs & -2.30 & -1.70 & -2.28 \\
\hline Impairment of receivables and deposits, net & -1.30 & -1.00 & -0.96 \\
\hline Impairment of investments in subsidiaries & - & - & - \\
\hline Government grant and other income & 2.47 & 2.89 & 2.37 \\
\hline Other operating expenses & -1.00 & -1.30 & -0.35 \\
\hline Depreciation and amortisation & -11.61 & -10.97 & -16.61 \\
\hline Finance income & 0.49 & 0.65 & -0.64 \\
\hline Finance costs & -0.42 & -4.72 & -5.46 \\
\hline Profit before tax & 25.77 & 30.56 & 31.78 \\
\hline Tax expenses & -6.41 & -7.41 & -8.41 \\
\hline Profit for the financial year & 19.36 & 23.14 & 23.37 \\
\hline
\end{tabular}

The revenues is considered as $100 \%$, and the profit before taxation is slightly decrease from $23.37 \%$ in 2016 to $23.14 \%$ in 2017 because of the traffic, commissions and other direct costs which lead to the decrease in profit before taxation, and its gradually decrease to $25.77 \%$ in 2018 because of other operating cost and the depreciation and amortisation cost. Thus, this will lead to the profit for the year from $23.37 \%$ in 2016 gradually decrease to $19.36 \%$ in 2018 because of the decrease in the profit before taxation even though the tax expenses is gradually decrease

Table 2. Digi Berhad Group Statement Profit or Loss at Year End 2018, 2017 \& 2016

\begin{tabular}{|l|c|c|c|}
\hline & $2018(\%)$ & $2017(\%)$ & $2016(\%)$ \\
\hline Revenue & 100.00 & 100.00 & 100.00 \\
\hline Other income & 0.30 & 0.33 & 0.28 \\
\hline Cost of materials and traffic expenses & -23.64 & -23.89 & -24.87 \\
\hline Sales and marketing expenses & -7.50 & -8.80 & -8.68 \\
\hline Operations and maintenance expenses & -1.78 & -2.04 & -1.69 \\
\hline Rental expenses & -5.45 & -6.28 & -5.38 \\
\hline Staff expenses & -3.89 & -3.90 & -3.86 \\
\hline Depreciation expenses & -10.07 & -9.85 & -7.89 \\
\hline Amortisation expenses & -2.26 & -2.54 & -1.99 \\
\hline Other expenses & -11.57 & -9.91 & -11.01 \\
\hline Finance costs & -1.99 & -2.09 & -1.18 \\
\hline Interest income & 0.32 & 0.37 & 0.19 \\
\hline Settlement costs and exit fee & - & -0.10 & - \\
\hline Operating model transition costs & -0.61 & - & - \\
\hline Profit before tax & 31.86 & 31.31 & 33.93 \\
\hline Taxation & -8.25 & -8.02 & -9.18 \\
\hline Profit for the year, representing total comprehensive income for the year & 23.61 & 23.29 & 24.75 \\
\hline
\end{tabular}


The revenues is considered as $100 \%$, and the profit before taxation is slightly decrease from $33.93 \%$ in 2016 to $31.31 \%$ in 2017 because of the operating expenses and finance cost. In addition, the settlement cost as well as the exit fee which lead to the decrease in profit before taxation. However, it slightly increase to $31.86 \%$ in 2018 because of the lower operating cost and reduction in finance costs. Thus, this will lead to the profit for the year from $24.75 \%$ in 2016 significantly decrease to $23.29 \%$ in 2017 and increase to 23.61 in 2018 because of the effect in the profit before taxation even though the tax expenses is decrease and then increase throughout the 3 years of Income Statement.

Table 3. Maxis Berhad Group Statement of Financial Position as at 31 December 2018, 2017 \& 2016

\begin{tabular}{|c|c|c|c|}
\hline & $2018(\%)$ & $2017(\%)$ & $2016(\%)$ \\
\hline \begin{tabular}{|l} 
ASSETS \\
NON-CURRENT ASSETS
\end{tabular} & & & \\
\hline Property, plant and equipment & 26.20 & 25.30 & 22.92 \\
\hline Intangible assets & 55.17 & 57.10 & 57.51 \\
\hline Investments in subsidiaries & - & - & - \\
\hline $\begin{array}{l}\text { Financial assets at fair value through other } \\
\text { comprehensive income }\end{array}$ & - & - & - \\
\hline Receivables, deposits and prepayments & 5.14 & 4.63 & 4.44 \\
\hline Derivative financial instruments & 0.01 & 0.01 & 2.39 \\
\hline Deferred tax assets & 0.00 & 0.04 & 0.23 \\
\hline TOTAL NON-CURRENT ASSETS & 86.53 & 87.09 & 87.49 \\
\hline $\begin{array}{l}\text { CURRENT ASSETS } \\
\text { Inventories }\end{array}$ & 0.08 & 0.02 & 0.03 \\
\hline Receivables, deposits and prepayments & 10.38 & 9.46 & 8.06 \\
\hline $\begin{array}{l}\text { Amount due from penultimate holding } \\
\text { company }\end{array}$ & - & - & 0.00 \\
\hline Amounts due from fellow subsidiaries & - & 0.01 & 0.00 \\
\hline Amounts due from related parties & 0.15 & 0.15 & 0.11 \\
\hline Amounts due from subsidiaries & - & - & - \\
\hline Loan to a subsidiary & - & - & - \\
\hline Derivative financial instruments & - & - & 0.73 \\
\hline Tax recoverable & 0.02 & 0.12 & 0.11 \\
\hline Deposits, cash and bank balances & 2.83 & 3.15 & 3.47 \\
\hline TOTAL CURRENT ASSETS & 13.47 & 12.91 & 12.51 \\
\hline TOTAL ASSETS & 100.00 & 100.00 & 100.00 \\
\hline $\begin{array}{l}\text { CURRENT LIABILITIES } \\
\text { Provisions for liabilities and charges }\end{array}$ & 0.58 & 0.58 & 0.49 \\
\hline Payables and accruals & 20.30 & 17.31 & 18.50 \\
\hline Amount due to a subsidiary & - & - & - \\
\hline Amounts due to fellow subsidiaries & 0.00 & 0.01 & - \\
\hline Amounts due to related parties & 0.03 & 0.12 & 0.07 \\
\hline Borrowings & 1.02 & 1.07 & 5.61 \\
\hline Derivative financial instruments & 0.00 & 0.01 & - \\
\hline Taxation & 1.00 & 1.52 & 0.77 \\
\hline TOTAL CURRENT LIABILITIES & 22.93 & 20.62 & 25.44 \\
\hline NON-CURRENT LIABILITIES & & & \\
\hline
\end{tabular}




\begin{tabular}{|l|l|l|l|} 
Provisions for liabilities and charges & 1.57 & 0.89 & 0.84 \\
Payables and accruals & 0.85 & 1.19 & 2.13 \\
Borrowings & 37.56 & 38.88 & 44.61 \\
Deferred tax liabilities & 0.99 & 2.12 & 2.95 \\
\hline TOTAL NON-CURRENT LIABILITIES & 40.97 & 43.08 & 50.53 \\
\hline EQUITY & 12.67 & 12.90 & 3.82 \\
Share capital & 23.43 & 23.40 & 20.21 \\
Reserves & 36.10 & 36.30 & 24.03 \\
\hline TOTAL EQUITY & & & \\
\hline
\end{tabular}

From the vertical analysis of assets of Maxis Berhad, the total assets are set up as 100\% where in 2016, the total non-current assets is $87.49 \%$ and total current assets is $12.51 \%$ as compared to 2017 where the total non-current assets is slightly decrease to $87.09 \%$, while the total current assets is slightly increase to $12.91 \%$. The decrease in total non-current assets is due to the company invest in the subsidiaries and there may be decrease in the amount of goodwill as it is measured based on cost less any impairment loss, while the total current assets is increasing because the receivables increase which indicates more sales generated and the sales are basically credits sales, thus lead to the decrease in the deposit, cash and bank balances. Furthermore, in 2018, the total non-current assets keep on decrease to $86.53 \%$ and the total current assets continue to increase to $13.47 \%$. This is what make the company to involve more in the current assets as compared to non-current assets

In the case of total equity and liability, we assume all at $100 \%$, and the total equity is significantly increase from 24.03 in 2016 to $36.30 \%$ in 2017 because the company may issue new share in that year, however it slightly decrease to $36.10 \%$ in 2018 because of the share issue cost. As for the total non-current liabilities, it is gradually decrease from $50.53 \%$ in 2016 to $40.97 \%$ in 2018 due to the decreasing amount of borrowings because it is measured at amortised cost and the certain amount of payables and acrruals has been settled throughout the year.

Furthermore, the current liabilities is significantly decrease from $25.44 \%$ in 2016 to $20.62 \%$ in 2017 because certain obligation of borrowing has been settled and some amount of payables has been paid. However, the current liabilities is slightly increase to $22.93 \%$ in 2018 due to increase in payables, which indicated there are new service rendered, that remain unpaid

Table 4. Digi Berhad Group Statement of Financial Position as at 31 December 2018, 2017 \& 2016

\begin{tabular}{|l|c|c|c|}
\hline & $2018(\%)$ & $2017(\%)$ & $2016(\%)$ \\
\hline ASSETS & & & \\
NON-CURRENT ASSETS & 46.43 & 49.87 & 51.51 \\
Property, plant and equipment & 15.82 & 16.06 & 8.25 \\
Intangible assets & - & - & - \\
Investments in subsidiaries & 0.00 & 0.00 & 0.00 \\
Other investment & 2.27 & 1.73 & 1.14 \\
Trade and other receivables & 1.15 & - & \\
Contract costs & 0.66 & - & - \\
Contract assets & 0.01 & 0.01 & - \\
Derivative financial assets & 66.33 & 67.67 & 60.91 \\
\hline TOTAL NON-CURRENT ASSETS & & & \\
\hline CURENT ASSETS & 0.99 & 1.01 & 0.87 \\
Inventories & & &
\end{tabular}


Jurnal Akuntansi \& Perpajakan

Vol. 5 (2) 2019: 57-70

\begin{tabular}{|l|c|c|c|} 
Trade and other receivables & 23.54 & 20.86 & 31.06 \\
Contract assets & 2.17 & - & - \\
Derivative financial instruments & - & - & 0.07 \\
Tax recoverable & - & 0.59 & 0.24 \\
Cash and short-term deposits & 6.98 & 9.86 & 6.85 \\
\hline TOTAL CURRENT ASSETS & 33.67 & 32.33 & 39.09 \\
\hline TOTAL ASSETS & 100.00 & 100.00 & 100.00 \\
\hline NON-CURRENT LIABILITIES & & & \\
Loans and borrowings & 40.49 & 46.14 & 32.72 \\
Deferred tax liabilities & 4.45 & 5.10 & 5.66 \\
Other liabilities & 0.79 & 0.76 & 0.73 \\
\hline TOTAL NON-CURRENT LIABILITIES & 45.72 & 51.99 & 39.11 \\
\hline CURRENT LIABILITIES & 34.55 & 33.05 & 35.43 \\
Trade and other payables & 5.08 & - & - \\
Contract liabilities & 0.00 & 0.02 & - \\
Derivative financial liabilities & 0.09 & 5.82 & 7.23 \\
Other liabilities & 2.92 & 0.22 & 8.79 \\
Loans and borrowings & 0.78 & 0.00 & 0.00 \\
\hline Tax payable & 43.43 & 39.12 & 51.45 \\
\hline TOTAL CURRENT LIABILITIES & 89.15 & 91.11 & 90.56 \\
\hline TOTAL LIABILITIES & & & \\
\hline EQUITY & 12.40 & 13.19 & 1.41 \\
Share capital & -1.55 & -4.30 & 8.03 \\
(Accumulated losses)/retained earnings & 10.85 & 8.89 & 9.44 \\
\hline TOTAL EQUITY & 100.00 & 100.00 & 100.00 \\
\hline TOTAL EQUITY \& LIABILITIES & & & \\
\hline
\end{tabular}

In case of vertical analysis of assets, the total assets of Digi Berhad remains at $100 \%$ but the total noncurrent assets increase rapidly from $60.91 \%$ in 2016 to $67.67 \%$ in 2017 because there is an increase in intangible as the company may had increase the value of spectrum right and acquire other intangible assets throughout the year. However, the non-current asset slightly decrease to $66.33 \%$ in 2018 because lower of plant, property and equipment even though there are contract cost and contracts assets incurred when right to consideration in exchange for goods or services (i.e. mobile devices or telecommunication services) transferred to the customer. As for the current assets, in 2016 the current assets has significantly decrease from $39.09 \%$ to $32.33 \%$ in 2017 because of the reduction in the trade and other receivable because of the efficient in the collection of trade receivable. However, in 2017, the company has a better cash and shortterm deposit compared to 2016 and 2018 cash and short-term deposits.

In the case of equities and liabilities of Digi Berhad, we assume that the total equities and liabilities are $100 \%$. However, the total equity is significantly decrease from $9.44 \%$ in 2016 to $8.89 \%$ in 2017 because the company may issue new share in 2017 but also incurred accumulated loss during the year. Meanwhile, in 2018 the equities increase significantly to $10.85 \%$. Even though the share capital is lower compared with the 2017 share capital but the accumulated loss in, 2018 is lower compared with 2017 accumulated loss. As for the non-current liabilities, it is drastically increase from $39.11 \%$ in 2016 to $51.99 \%$ in 2017. However, in 2018 the percentage is decreasing to $40.49 \%$ as they might only obligated to pay the interest from the loan obtained and the company's effort to reduced its liabilities. For current liabilities, it has drastically decrease from $51.45 \%$ in 2016 to $39.12 \%$ in 2017 because the reduction of the trade payables due to certain obligation has been paid. However, it significantly increase to $43.43 \%$ in 2018 because of contract liabilities is recognised when consideration is received from the customer, but services are yet to be performed. 


\section{RATIO ANALYSIS}

\section{PROFITABILITY RATIOS}

Profitability ratios are one of the most frequently used tools of financial analysis to determine the company's performance to generate income against its assets, equity and expenses over time. Higher ratio results are often more favorable, but it is more meaningful when compared to other similar companies.

Table 5. Profitability ratios of Digi.Com Berhad and Maxis Berhad

\begin{tabular}{|l|c|c|c|c|c|c|}
\hline Company & \multicolumn{3}{|c|}{ Digi.Com Berhad } & \multicolumn{3}{c|}{ Maxis Berhad } \\
\hline Year & $\mathbf{2 0 1 6}$ & $\mathbf{2 0 1 7}$ & $\mathbf{2 0 1 8}$ & $\mathbf{2 0 1 6}$ & $\mathbf{2 0 1 7}$ & $\mathbf{2 0 1 8}$ \\
\hline Net profit margin & $24.75 \%$ & $23.29 \%$ & $23.61 \%$ & $23.37 \%$ & $23.14 \%$ & $19.36 \%$ \\
\hline Operating income margin & $34.64 \%$ & $32.70 \%$ & $33.23 \%$ & $34.24 \%$ & $31.75 \%$ & $27.05 \%$ \\
\hline Total asset turnover & 1.20 & 1.09 & 1.05 & 0.54 & 0.57 & 0.55 \\
\hline Return on asset & $29.7 \% \%$ & $25.3 \%$ & $24.8 \%$ & $12.6 \%$ & $13.1 \%$ & $10.6 \%$ \\
\hline Return on total equity & $314.6 \%$ & $284.6 \%$ & $229.0 \%$ & $45.2 \%$ & $37.6 \%$ & $25.3 \%$ \\
\hline
\end{tabular}

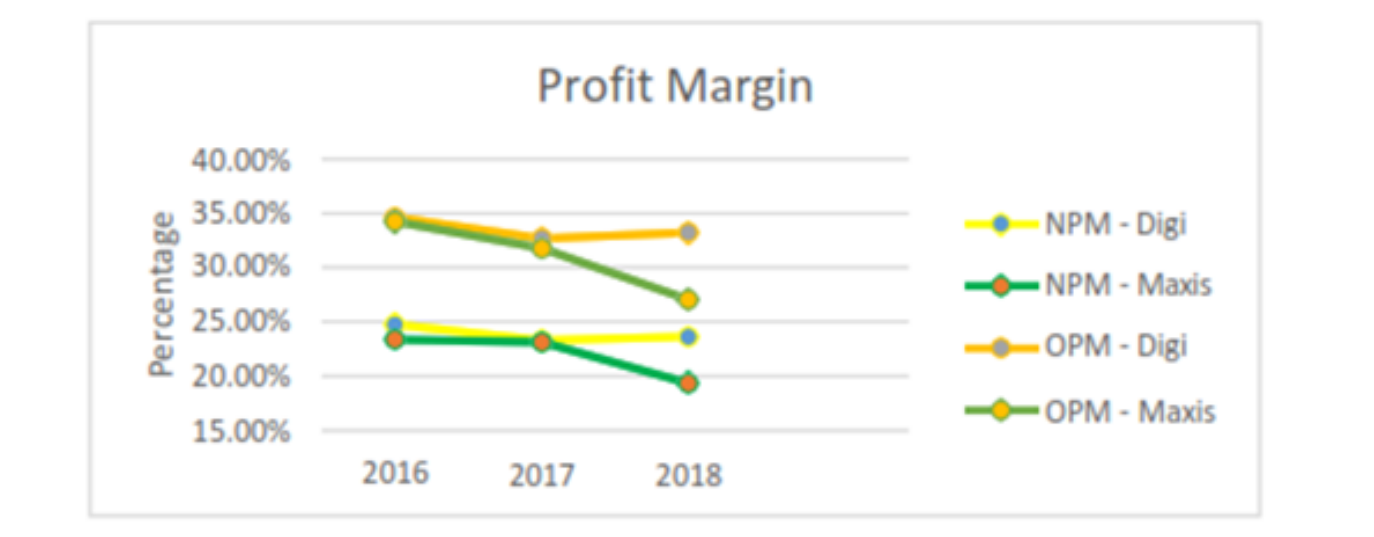

Figure 1. Profit Margin

Based on Table 1, the net profit margin of Digi.Com Berhad slightly dropped in year 2017 from $24.75 \%$ to $23.29 \%$ due to decrease in telecommunication revenue and other income and also due to higher depreciation expenses for the year 2017. Even though in year 2018 there is an increase in postpaid and prepaid internet revenue growth, the cost of goods sold have rose $1.9 \%$ too due to higher device cost arising from demand for contracted device bundles and the new PhoneFreedom 365 program that lead to only a slightly increase of net profit margin $(23.61 \%)$. While Maxis Berhad's net profit margin shows a declining trend and it has a significant dropped in year 2018 which only have $19.36 \%$ of net profit margin. Even though the revenue has increased in year 2017 due to high demand for high quality network data, the net profit margin for year 2017 is decreased by $0.23 \%$ due to increase in expenses. In year 2018, there is a significant dropped in net profit margin of Maxis Berhad, which only have $19.36 \%$ net profit margin compared to Digi.Com Berhad, due to lower revenue earned in the first half of the year 2018 and higher expenses incurred compared to last year.

Operating income margin for Digi.Com Berhad trimmed from 34.64\% (2016) to 32.70\% (2017) due to high depreciation expenses and settlement costs exit fee in year 2017. In year 2018, operating income margin for Digi is slightly increase from $32.70 \%$ to $33.23 \%$ due to increase in revenue and flat operating expenses. While operating income margin for Maxis Berhad have dropped significantly from $34.24 \%$ (2016) to $27.05 \%$ (2018) due to reduction in service revenue and high operating expenses. 


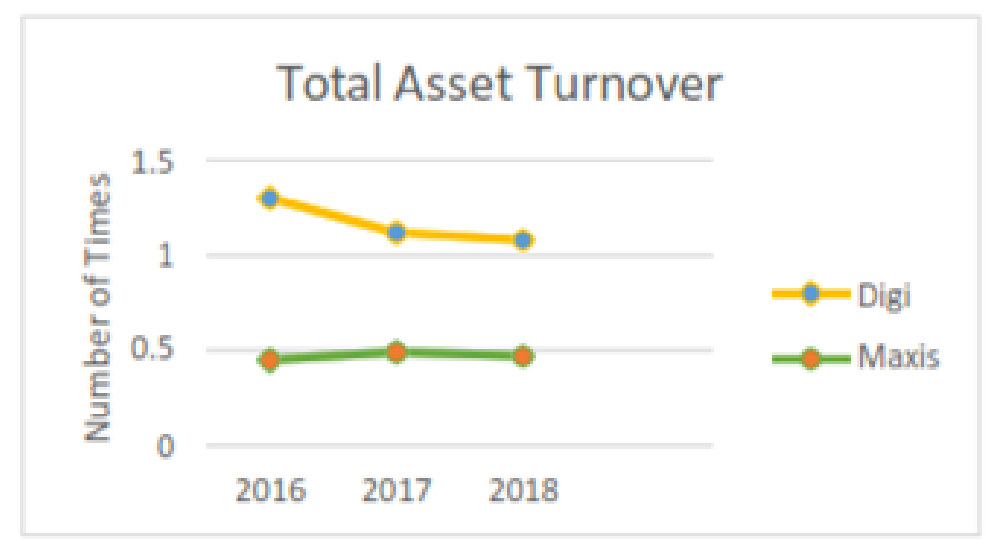

Figure 2. Total Asset Turnover

Total assets turnover measures the efficiency of a company's assets to generate revenue. Based on Table 1, Digi.Com Berhad have higher total assets turnover from its competitor, Maxis Berhad. Digi's total asset turnover is more than 1 due to lower amount of assets compared to Maxis but relatively similar amount of revenue earned. Digi is doing better than Maxis where the revenue earned is RM1.20 for every RM1.00 in assets for year 2016. While for Maxis, they were only able to generate RM0.54 for every RM1.00 assets invested in the same comparative year 2016. Digi is able to maintain their total asset turnover ratio above 1 from year 2016 until 2018 and this indicates that Digi is more efficient in using their assets to gain revenue.

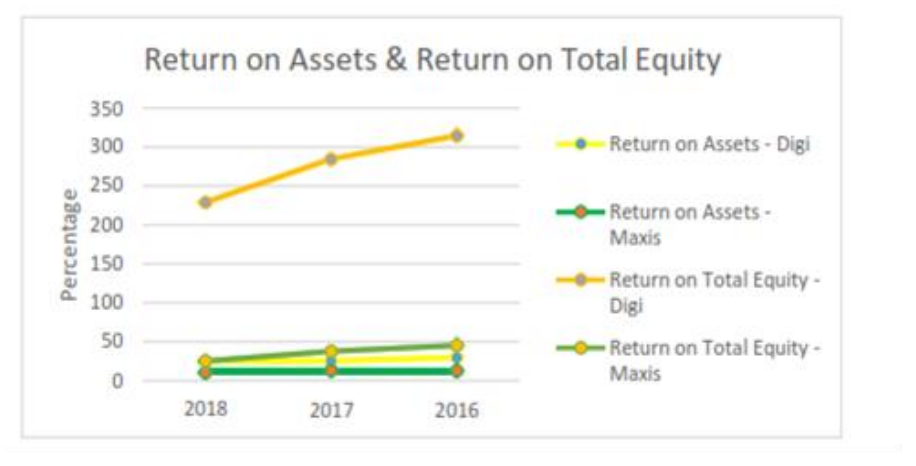

Figure 3. Return on Assets \& Return on Total Equity

Return on asset (ROA) measures the company's ability to utilize its assets to earned net income. ROA is differs from total asset turnover ratio since ROA use net income while total asset turnover use revenues. Digi.Com Berhad's return on asset decreased from 29.7\% (2016) to $24.8 \%$ (2018) due to decrease in telecommunication revenue in year 2017 and higher expenses such as cost of goods sold, higher device cost arising from demand for contracted device bundles and the new PhoneFreedom 365 program in year 2018. While return on asset for Maxis Berhad, does increase from 12.6\% (2016) to 13.1\% (2017) contributed by higher income generated from other income such as finance income, government grant and other income. In year 2018, return on asset for Maxis decreased to $10.6 \%$ due to lower income generated and high expenses incurred

Return on equity (ROE) measures the company's abilities to utilize its equity to earned net income. Return on equity of Digi.Com Berhad shows a declining trend from 314.6\% in year 2016 until $229 \%$ in year 2018. Maxis Berhad's return on equity also shows a declining trend too due to the same reasons. These declining trends happen due to low revenues earned and high expenses incurred that leads to lower net income and also due to materially increase in amount of equity. To compare, Digi.Com Berhad's return on equity is significantly higher than Maxis. This shows that Digi is much more efficient in generating profit by using the capital that shareholders have invested in the company 


\section{EFFICIENCY RATIOS}

The efficiency ratios measure a company's ability to use its assets and manage its liabilities effectively. Some efficiency ratios include the account receivable turnover, inventory turnover and fixed assets turnover. These ratios measure how efficiently a company uses its assets to generate revenues and its ability to manage those assets. The following is the calculation of efficiency ratios for Maxis Berhad and Digi Berhad.

Table 6. Efficiency Ratios of Maxis Berhad and Digi Berhad

\begin{tabular}{|l|c|c|c|c|c|c|}
\hline \multicolumn{2}{|c|}{ Company } & \multicolumn{3}{c|}{ Maxis } & \multicolumn{3}{c|}{ Digl } \\
\hline \multicolumn{1}{|c|}{ Years } & $\mathbf{2 0 1 8}$ & $\mathbf{2 0 1 7}$ & $\mathbf{2 0 1 6}$ & $\mathbf{2 0 1 8}$ & $\mathbf{2 0 1 7}$ & $\mathbf{2 0 1 6}$ \\
\hline Day's sale in account receivable & 81 days & 66 days & 69 days & 82 days & 70 days & 58 days \\
\hline Account receivable turnover & 5.57 times & $\begin{array}{c}6.49 \\
\text { times }\end{array}$ & $\begin{array}{c}6.48 \\
\text { times }\end{array}$ & $\begin{array}{c}4.75 \\
\text { times }\end{array}$ & $\begin{array}{c}5.48 \\
\text { times }\end{array}$ & $\begin{array}{c}7.19 \\
\text { times }\end{array}$ \\
\cline { 2 - 8 } & 64 days & 55 days & 55 days & 75 days & 65 days & 50 days \\
\hline Day's sale in inventory & 2 days & 1 day & 1 day & 14 days & 14 days & 10 days \\
\hline Inventory turnover & 294.91 & 597.26 & 283.67 & 25.66 & 28.32 & 19.93 \\
& times & times & times & times & times & times \\
\cline { 2 - 8 } & 1 day & 1 day & 1 day & 14 days & 13 days & 18 days \\
\hline Operation cycle & 65 days & 55 days & 56 days & 89 days & 78 days & 67 days \\
\hline
\end{tabular}

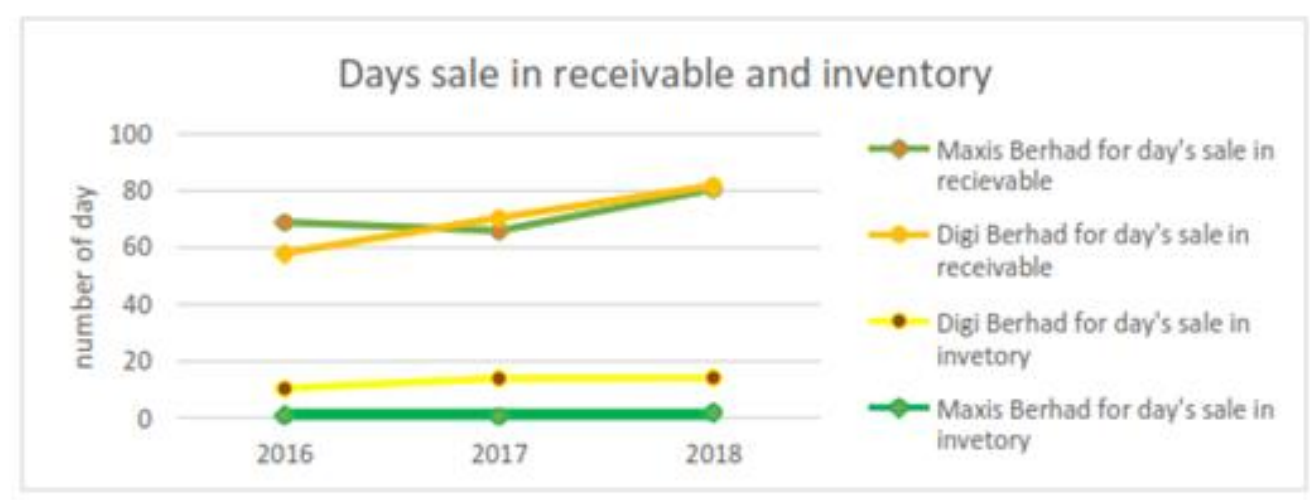

Figure 4. Days Sale in Receivable and Inventory

Day's sale in receivable measures the length of times that the receivables have been outstanding. Maxis Berhad able to collect customers' payments on account receivable is stronger than Digi Berhad, with Maxis Berhad taking 52 days on average that within credit term of 60 days as compared to Digi Berhad's 70 days higher than their credit term of 30 to 60 days. While both companies' collection period was longer than the normal business benchmark of 30 days.

Day's sale in inventory measures on the length of time needed to sell all inventory on hand. Maxis Berhad able to convert the inventory ready to sale is stronger than Digi Berhad, with Maxis Berhad taking a day on average that within credit term of 60 days as compared to Digi Berhad's 70 days higher than their credit term of 30 to 60 days. While both companies' collection period was longer than the normal business benchmark of 30 days 


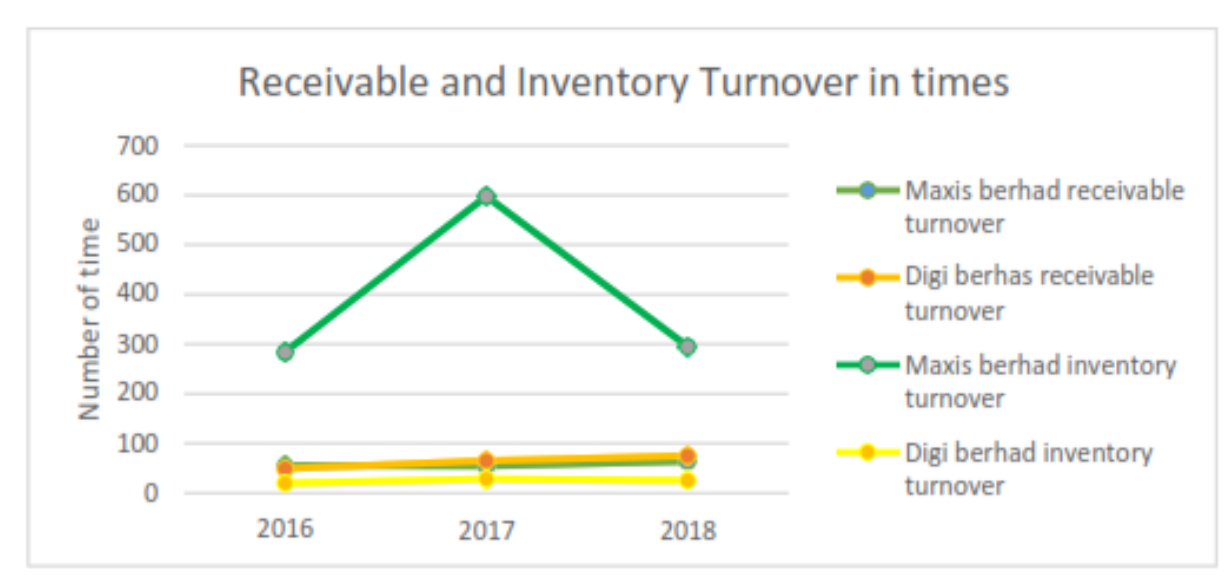

Figure 5. Receivable and Inventory Turnover in times

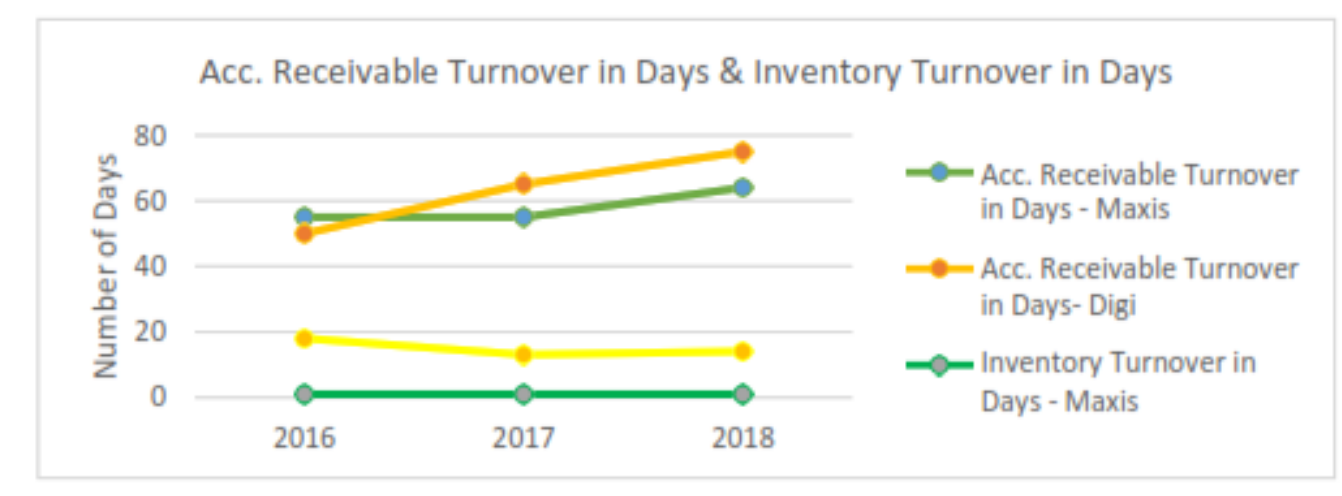

Figure 6. Account Receivable Turnover in Days \& Inventory Turnover in Days

Account receivable turnover rate indicate how quickly receivables are collected. Generally, a high value of account receivable turnover rate is favourable while lower value may indicate in efficiency in collecting outstanding sales. For Maxis Berhad, the account receivable turnover is slightly increasing for two years of 2016 and 2017 which are 6.48 times and 6.49 times respectively. However, in the year 2018 decrease to 5.57 times. While for Digi Berhad, the account receivable turnover is decreasing for three years of 2016, 2017 and 2018 which are 7.19 times, 5.48 times and 4.75 times respectively.

This resulted in Maxis Berhad has high account receivable's turnover which implies that the company has operated on a cash basis or the extension of credit and the company has aggressively in collection of account receivables that are efficient more than Digi Berhad. For Maxis Berhad, the account receivable turnover in days is the remain in two years of 2016 and 2017 which are at 55 days. However, in the year 2018 increasing to 65 days. While for Digi Berhad, the account receivable turnover in days is increasing for three years of 2016, 2017 and 2018 which are 50 days, 65 days and 75 days respectively

Inventory turnover rate Indicates the liquidity of inventory. For Maxis Berhad, the inventory turnover is increasing for two years of 2016 and 2017 which are 283.67 times and 597.26 times respectively. However, in the year 2018 decrease to 294.91 times. While for Digi Berhad, the account inventory turnover is also increase for two years of 2016 and 2017 which are 19.93 times and 28.32 times respectively. However, in the year 2018 decrease to 25.66 times.

The significant different in inventory turnover between Maxis Berhad and Digi Berhad is due to the product offer by both companies. Maxis Berhad have variety product line offered such as in telecommunication and internet services provider. The increase of sale indicate that the turnover of inventory is higher times due to high demand from the customer when they purchase the services along with the devices such as modem and portable Wi-Fi. While Digi Berhad have only provide the telecommunication service provider. Thus, the amount of inventory turnover is higher compare to Maxis Berhad. This also reflect on the inventory turnover in days. For Maxis Berhad remain a day due to the fast rolling of inventory based on the demand of customer as compare to Digi Berhad 


\section{LEVERAGE RATIO}

Leverage ratio are used to determine the relative level of debt load that a business has incurred

Table 7. Leverage Ratios of Digi Berhad \& Maxis Berhad

\begin{tabular}{|l|c|c|c|c|c|c|}
\hline \multirow{2}{*}{ LEVERAGE RATIO } & \multicolumn{3}{|c|}{ DIGI } & \multicolumn{3}{c|}{ MAXIS } \\
\cline { 2 - 7 } & 2016 & 2017 & 2018 & 2016 & 2017 & 2018 \\
\hline Debt Ratio & 0.91 & 0.91 & 0.89 & 0.76 & 0.64 & 0.64 \\
\hline Debt / Equity Ratio & 9.59 & 10.25 & 8.22 & 3.16 & 1.75 & 1.77 \\
\hline
\end{tabular}

These ratios compare the total debt obligation to either the assets or equity of a business.

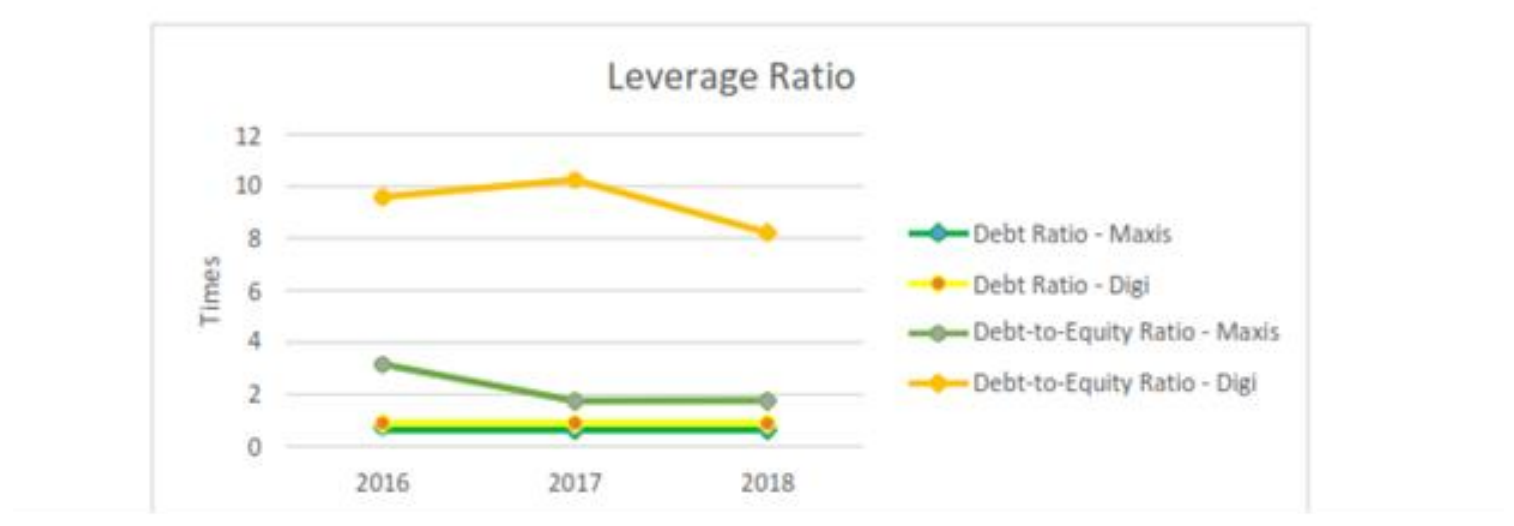

Figure 7. Leverage Ratio

Based on the ratio in the table above, it clearly showed that Maxis Berhad has more favourable ratio as compared to DIGI Berhad. It showed that Maxis Berhad has more stable business with potential of longevity because the company has lower ratio and has lower overall debt. From the comparison, we can see that DIGI berhad has a higher value of debt ratio that Maxis Berhad. A high debt ratio can put DIGI Berhad at risk for a serious financial crisis, including bankruptcy or property foreclosure. The two basic ways to lower debt ratio proportions are to increase income or decrease expenses. For DIGI Berhad, its debt ratio is remain the same in 2016 and 2017 of $0.91 \%$ and slightly decrease to $0.89 \%$ in 2018, meanwhile Maxis Berhad debt ratio from 2016 is higher of $0.76 \%$ compared in year 2017 and 2018 of $0.64 \%$.

Based on the table above, DIGI Berhad has a higher ratio than Maxis Berhad, which indicates that the company may not be able to generate enough cash to satisfy its debt obligation. For Maxis Berhad, which has a lower debt to equity ratio indicate that the company are, more financially stable in the market. Besides that Maxis Berhad, starting from year 2016, the debt to equity ratio has significantly decrease from $3.16 \%$ to $1.75 \%$ in year 2017 and slightly increase to $1.77 \%$ in year 2018. However, for DIGI Berhad, in 2016 the debt to equity ratio is slightly increase from $9.59 \%$ to $10.25 \%$ in year 2017 , while it slightly decrease to $8.22 \%$ in year 2018. A higher ratio in DIGI Berhad, it might be because the investors do not want to fund the business operation because the company is not performing well.

\section{LIQUIDITY RATIO}

Liquidity ratio are measurements used to examine the ability of the company to pay its short-term obligation. These ratio compare various combinations of relative liquid assets to the amount of current.

Table 8. Liquidity Ratios of Maxis Berhad and Digi Berhad

\begin{tabular}{|l|c|c|c|c|c|c|}
\hline \multirow{2}{*}{ LIQUIDITY RATIO } & \multicolumn{3}{|c|}{ DIGI } & \multicolumn{3}{c|}{ MAXIS } \\
\cline { 2 - 7 } & 2016 & 2017 & 2018 & 2016 & 2017 & 2018 \\
\hline Working Capital & $(679,288)$ & $(395,993)$ & $(605,396)$ & $(2,538,728)$ & $(1,474,604)$ & $(1,874,356)$ \\
\hline Current Ratio & 0.76 & 0.83 & 0.77 & 0.49 & 0.63 & 0.59 \\
\hline Acid-Test /Quick Ratio & 0.74 & 0.80 & 0.75 & 0.49 & 0.63 & 0.58 \\
\hline Cash Ratio & 0.13 & 0.25 & 0.16 & 0.14 & 0.15 & 0.12 \\
\hline
\end{tabular}


Liabilities stated in the company's balance sheet.

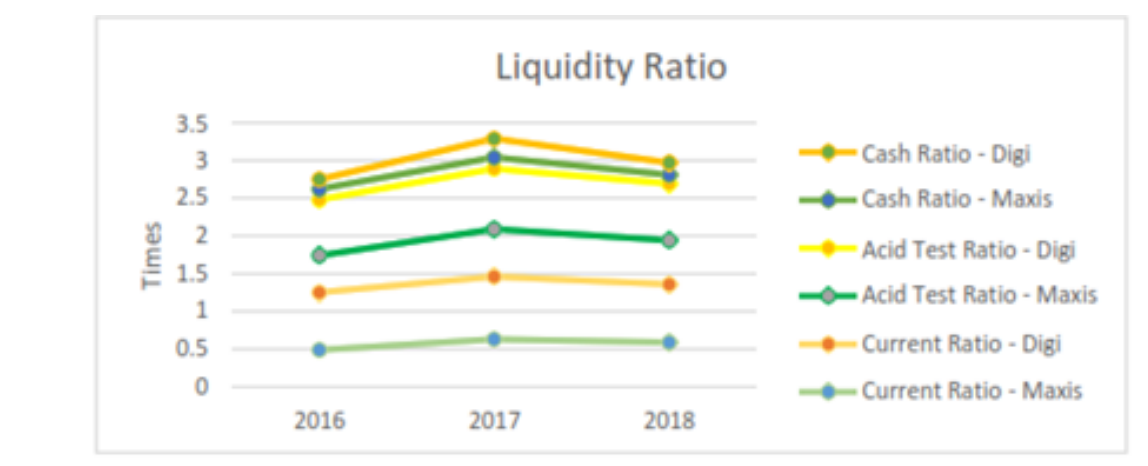

Figure 8. Liquidity Ratio

Working Capital is an indication of the short run solvency of the business. From the table above, it shows that both company have negative working capital, which means that the business doesn't have enough liquid assets to meet it current or short-term obligations. The net working capital is negative due to inefficient asset management and poor cash flow. If the business does not have enough cash to pay the current liabilities as they become due, the business will have to incur more loans and borrowing to meets its short-term obligation. Both company's current liabilities cannot meet its current obligation with current assets, hence the company will be forced to use its long-term assets to pay off its current obligation

Current ratio is to determine short-term debt-paying ability. The current ratio shows from year 2016 to 2018, which DIGI Berhad has more assets to cover its liabilities where they have 0.76 times available to pay its debt. The cash to current asset ratio and cash to current liabilities ratio showed a significantly increased to 0.83 times in 2017 and slightly decrease to 0.77 times in 2018. While for Maxis Berhad, only 0.49 times of assets are available to pays its debt, and significantly increase to

0.63 times in 2017, and slightly decrease to 0.59 times in 2018. The significant increase of current ratio in 2017 is because both companies have meets it obligation thus lead to decrease in the current liabilities. In the table above, Digi Berhad has a better coverage of liquidity assets to short-term liabilities compared to Maxis Berhad.

The acid test ratio is significantly increase from 0.74 times in 2016 to 0.80 times in 2017 due the increase in inventory that may be obsolete or cannot be converted easily. However, it decrease to 0.75 times in 2018 because of the increased in the trade receivables and increase in inventory. As for Maxis Berhad, its liquidity of the assets is lower compared to Digi Berhad, which it increase significantly in 2017 and decrease slightly in 2018. Thus, the company should improves its liquidity in order to meets its current obligations.

Cash ratio indicates the immediate liquidity of the firm. For Digi Berhad, the cash ratio shows a significant increase from 0.13 times to 0.25 times in 2017 which indicates there is an increase the cash and short-term deposit and the lower of trade payables also lead to high cash ratio. However, it gradually decrease to 0.16 in 2018 due to high trade payables even though the cash is high. However, cash ratio for Digi Berhad is better compared with Maxis Berhad, which slightly increase in 2016 to 2017 and decrease to 0.12 times in 2018 and there are not many changes in the cash ratio. Thus, Digi berhad has better liquidity position in term of cash compared to Maxis Berhad because it may be difficult to meet its short-term debt

\section{MARKET RATIOS}

Market value ratios are used to evaluate the current share price of a publicly-held company stock. It is also called as investor ratio. These ratios are employed by current and potential investor to determine whether a company's share are over-priced or under-priced. 
Table 9. Market ratios of Maxis Berhad and Digi Berhad

\begin{tabular}{|l|c|c|c|c|c|c|}
\hline COMPANY & \multicolumn{3}{|c|}{ DIGI BERHAD } & \multicolumn{3}{c|}{ MAXIS BERHAD } \\
\hline Years & 2016 & 2017 & 2018 & 2016 & 2017 & 2018 \\
\hline Earnings Per Share (RM) & RM0.21 & RM0.19 & RM0.20 & RM0.27 & RM0.28 & RM0.23 \\
\hline Price-earnings Ratio (Times) & 23 Times & 26.84 Times & 22.5 Times & 22.15 Times & 21.46 Times & 23.26 Times \\
\hline Dividend Payout Ratio (\%) & $99.52 \%$ & $98.95 \%$ & $98 \%$ & $74.07 \%$ & $71.43 \%$ & $86.96 \%$ \\
\hline Dividend Yield (\%) & $4.33 \%$ & $3.69 \%$ & $4.36 \%$ & $3.34 \%$ & $3.33 \%$ & $3.74 \%$ \\
\hline
\end{tabular}

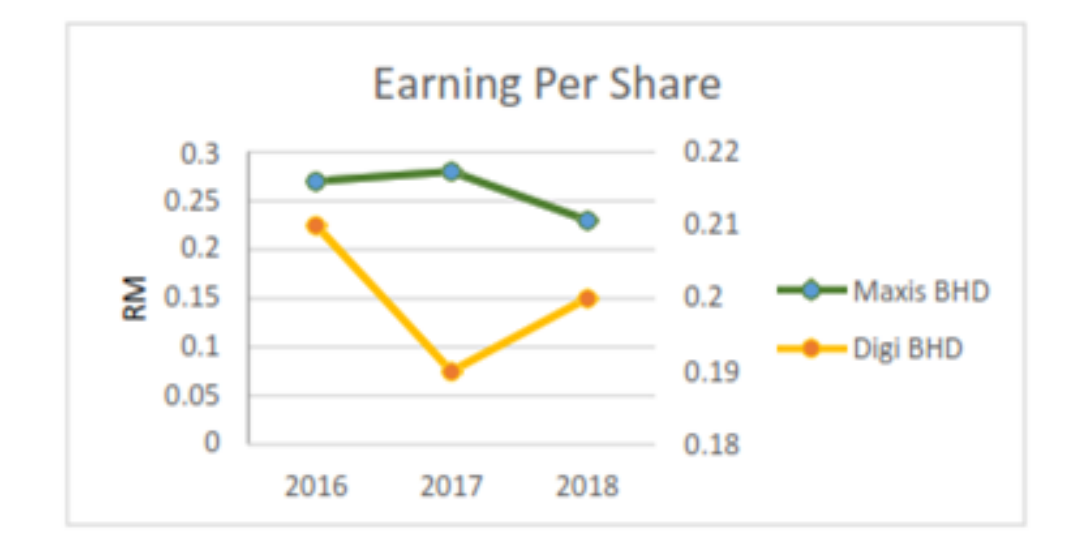

Figure 9. Earning Per Share

Earnings per share (EPS) are the amount of income earned of a share of common stock during an accounting period. From the graph above, the earning per share of Digi Berhad slightly decrease from RM0.21 in 2016 to RM0.19 in 2017. However, in 2018 the earning per share of Digi Berhad is slightly increase by RM0.01. While, earnings per share of Maxis Behad is slightly increase from RM0.27 in 2016 to RM0.28 in 2017 but in 2018 it increase to RM0.23. Digi Berhad had increasing trend of earning per share (EPS) from 2017 to 2018 while Maxis Berhad had increasing trend in the year 2016 until 2017 due to its stronger performance of profit. An increase value indicates a high profit per share and this will of course be preferred by the existing shareholders as well as potential investors

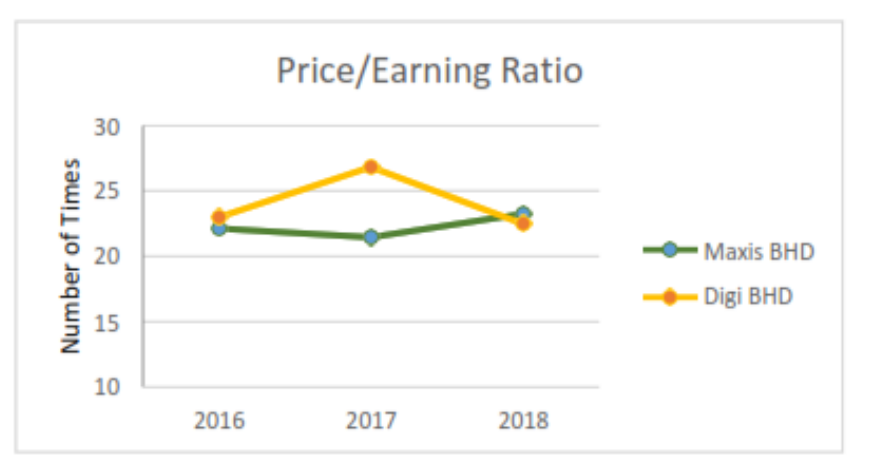

Figure 10. Price/Earning Ratio

Price-Earnings Ratio (P/E Ratio) measure the relationship between the market price of a share of common stock and that stock's current earning per share. From the graph above, the P/E ratios of Digi Berhad had increase significantly from 23 times in 2016 to 26.84 times in 2017 however in 2018 the P/E ratios drop significantly to 23.26 time. The higher of $\mathrm{P} / \mathrm{E}$ ratios from 2016 to 2017 because of the increase of market price per share hence it indicate the company's stock more expensive when compare with earnings. Furthermore, the higher the P/E ratios from 2016 until 2017 indicate the higher is the investment confidence in Digi Berhad. Meanwhile, in 2018 the P/E ratios drop significantly due to decrease in market price per share in 2018 and also due to increase in its loan and borrowing (debt) in 2018 amounted to RM 181,371 . Therefore it causes the P/E ratios for its stock decline 
Meanwhile for Maxis Berhad, the P/E ratio had slightly decreased from 22.15 times in 2016 to 21.46 times in 2017. However in 2018 the P/E ratios had slightly increased to 22.5 times. We can see that, Digi Berhad had a better performance as compared to Maxis Berhad because high P/E ratio usually indicate positive future performance and investor are willing to pay more for this company's shares

Dividend payout ratio measures the portion of current earnings per common share being paid out in dividend. Based on the graph above, dividend payout ratio for Digi Berhad had slightly decreased in its percentages from $99.52 \%$ in 2016 to $98 \%$ in 2018. Meanwhile, dividend payout ratio for Maxis Berhad had slightly decreased from $74.07 \%$ in 2016 to $71.43 \%$ in 2017 . However in 2018 the percentage of dividend payout ratio had increase significantly to $86.96 \%$. We can see that Digi Berhad had drop in their dividend payout ratio but still maintain high in its ratio due to its policy and it indicates that a company as sharing more of its earnings with stockholders. The dividend policy will be maintained subject to ongoing assessment, and based on the availability of distributable reserves as well as the Group's future cash flow requirements and market conditions.

Dividend Yield indicates the relationship between the dividend per common share and the market price per common share. The yield is depending on a firm's dividend policy and market price. From the graph above, dividend yield for Digi Berhad had decrease in its ratio from 4.33\% in 2016 to 3.69 in 2017. However, in 2018 the dividend yield for Digi Berhad had increased significantly to $4.36 \%$. The decreasing trend from 2016 until 2017 is due to increase of market share price from RM4.83 to RM5.10. However, the increasing trend of Digi Berhad in 2018 is due to declining in market share price which is RM4.50. Meanwhile, dividend yield for Maxis Berhad had slightly decreased in its ratio from 3.34\% in 2016 to 3.33\% in 2017. However, in 2018 the dividend yield for Maxis Berhad had increased to 3.74\%. The fluctuation of ratio is due to the fluctuation of market share price. In conclusion, the dividend yields of Digi Berhad are higher compare to its competitor, Maxis Berhad for the Year 2016 until Year 2018. The investor will be more confidence to invest in Digi Berhad compare to Maxis

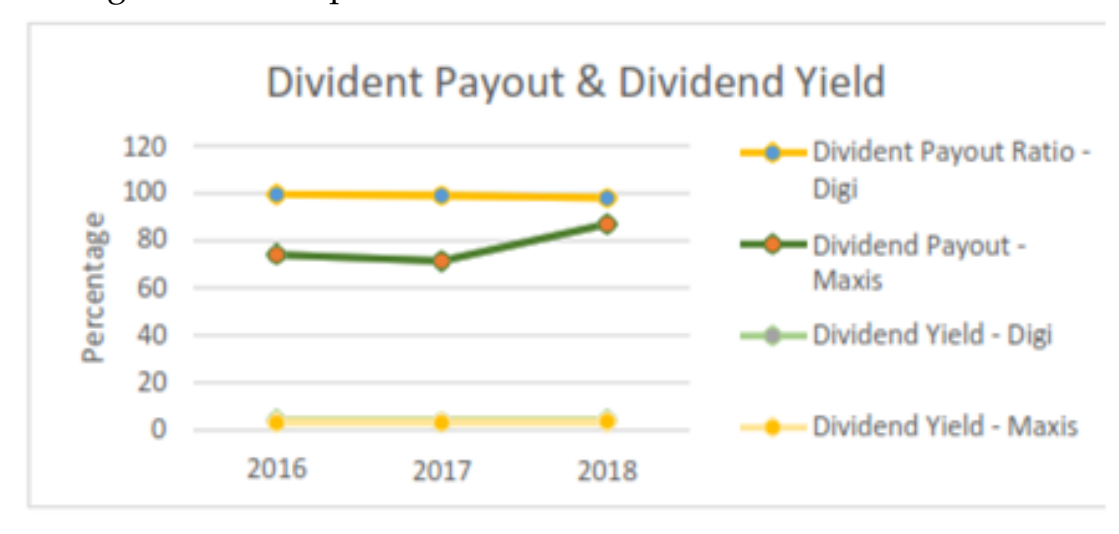

Figure 11. Divident Payout \& Dividend Yield

Dividend payout ratio measures the portion of current earnings per common share being paid out in dividend. Based on the graph above, dividend payout ratio for Digi Berhad had slightly decreased in its percentages from $99.52 \%$ in 2016 to $98 \%$ in 2018. Meanwhile, dividend payout ratio for Maxis Berhad had slightly decreased from $74.07 \%$ in 2016 to $71.43 \%$ in 2017 . However in 2018 the percentage of dividend payout ratio had increase significantly to $86.96 \%$. We can see that Digi Berhad had drop in their dividend payout ratio but still maintain high in its ratio due to its policy and it indicates that a company as sharing more of its earnings with stockholders. The dividend policy will be maintained subject to ongoing assessment, and based on the availability of distributable reserves as well as the Group's future cash flow requirements and market conditions.

Dividend Yield indicates the relationship between the dividend per common share and the market price per common share. The yield is depending on a firm's dividend policy and market price. From the graph above, dividend yield for Digi Berhad had decrease in its ratio from 4.33\% in 2016 to 3.69 in 2017. However, in 2018 the dividend yield for Digi Berhad had increased significantly to $4.36 \%$. The decreasing trend from 2016 until 2017 is due to increase of market share price from RM4.83 to RM5.10. However, the increasing trend of Digi Berhad in 2018 is due to declining in market share price which is RM4.50. 
Meanwhile, dividend yield for Maxis Berhad had slightly decreased in its ratio from 3.34\% in 2016 to $3.33 \%$ in 2017. However, in 2018 the dividend yield for Maxis Berhad had increased to 3.74\%. The fluctuation of ratio is due to the fluctuation of market share price. In conclusion, the dividend yields of Digi Berhad are higher compare to its competitor, Maxis Berhad for the Year 2016 until Year 2018. The investor will be more confidence to invest in Digi Berhad compare to Maxis Berhad

\section{CONCLUSION}

In conclusion, we can conclude that the financial statement analysis on both public listed companies which are Maxis Berhad and Digi Berhad have similarities and differences. By preparing this report, we can see the growth of companies in the market and to get a better financial view of the current trends in telecommunication industry as we calculated, analyzed and interpreted the ratios based on the information and finding in the financial statement. We also evaluate on the performance of both companies in market by observing the chairman's statement in each annual report for both companies. We also make comparison to the industry average to identify the position of the companies in the industry. The analysis show Digi have better profitability ratios than Maxis Berhad. Efficiency ratio for both companies is almost the same performance. Digi have higher leverage ratio and higher liquidity ratio. Maxis have better market ratio.

\section{REFERENCES}

http://digi.listedcompany.com/ar.html

https://ocs.digi.com.my/aboutus/home.html

https://maxis.listedcompany.com/ar.html

https://www.maxis.com.my/about-maxis/

https://www.bloomberg.com/profile/company/2201Z:MK

https://www.telenor.com/about-us/global-presence/malaysia/

https://en.m.wikipedia.org/wiki/Digi_Telecommunications 